\title{
Good Waqf Governance and its Contribution in Sustainable Development
}

\author{
Saripah Abdul Latif1, Nik Muniyati Nik Din² , Zaiton Mustapha³ \\ ${ }^{1}$ Faculty of Business and Management, \\ ${ }^{2}$ Academy of Contemporary Islamic Studies, \\ ${ }^{3}$ Academy of Language Studies, \\ Universiti Teknologi MARA Kelantan, Kota Bahru Campus, Malaysia \\ saripah5998@gmail.com
}

\begin{abstract}
Waqf is an Islamic charity institution which should be able to act as the catalyst for sustainable development, if the institution is systematically and optimally implemented. However, a substantial proportion of total waqf is still lying dormant across the world. The aim of the study is to obtain a better understanding in waqf governance issues. An exploratory research design is carried out on the authority which is responsible for the implementation of waqf governance in Kelantan, a state in Malaysia. The findings showed that legislation and inefficient management are among the possible impeding factors for good governance of waqf.
\end{abstract}

Keywords: Waqf Governance, Sustainable Development

eISSN 2514-7528 @ 2019. The Authors. Published for AMER ABRA CE-Bs by e-International Publishing House, Ltd., UK. This is an open-access article under the CC BY-NC-ND license (http://creativecommons.org/licenses/bync-nd/4.0/). Peer-review under responsibility of AMER (Association of Malaysian Environment-Behaviour Researchers), ABRA (Association of Behavioural Researchers on Asians) and cE-Bs (Centre for EnvironmentBehaviour Studies), Faculty of Architecture, Planning \& Surveying, Universiti Teknologi MARA, Malaysia.

https://doi.org/10.21834/jabs.v4i12.328 


\subsection{Introduction}

The three domains of sustainable development are the environment, the economy and the society. These three domains have been included in the set of 17 Sustainable Development Goals (SDGs) by United Nations General Assembly in 2015, whose objectives are to end poverty, protect the planet and ensure prosperity for all. This is part of a new sustainable development agenda for the world to be achieved in a period of fifteen years (http://sustainabledevelopment.un.org/sdgs)

. Prior to this, in their 2011 study, Patmawati et al. observed that development involved economic growth, increases in per capita income and attainment of a standard of living equivalent to that of industrialized nations. Sustainable development ensures the well-being of humankind by integrating social development, economic development and environmental conservation and protection. A nation's economic development is related to its human development, which encompasses, among other things, health and education. Patmawati et al. (2011) further stated that social and economic development reinforces and depend on one another for the full realization of sustainable development. According to Farhana Mohamad Suhaimi et al (2014), development is a multi-dimensional process involving restructuring and welfare improvement through spiritual advancement based on Islamic values.

Waqf is an Islamic institution which existed since the time of the Prophet Muhammad saw. It brings together both the spiritual and materials elements. Based on its nature, waqf actually acts as the catalyst for economic growth as well as the human development, provided that the institution is systematically and optimally implemented. Socially, waqf enables the birth of responsible and accountable citizens which will eventually promote sustainable development.

One of the missions of Islamic Development Bank (IDB) that is hoped to be executed through waqf and zakat is to foster innovative and sustainable solutions to the world's greatest development challenges (IDB,2014). This is in line with the above mentioned United Nations Sustainable Development Goals (SDGs).

Literally waqf means to stop, contain, or to preserve. In shari'ah, a waqf is a voluntary, permanent, irrevocable dedication of a portion of one's wealth - in cash or kind - to Allah (International Islamic University Malaysia, 2017). It is further explained that once it is a waqf, it never gets gifted, inherited, or sold. It belongs to Allah and the corpus of the waqf always remains intact. And the fruits of the waqf may be utilized for shari'ah complient purposes. Zakaria, Abd Samad \& Shafii (2012) defined waqf as private ownership or asset in any form that has been put under injunction from any form of deal including sale, inheritance and heirloom, hibah(grant) and wasiyyah(will), at the same time as its physical source remains whole and unaffected. To put it simply, a waqf is a sustainable development institution, a sadaqah jariyyah, a capital gift to Allah, a legacy for the future, a revival of the Sunnah, a beautiful loan to Allah, a social responsibility investment, a dedication to Allah, an ibadat, a civil social society initiative, an enduring endowment and it is a contribution to nation-building, poverty alleviation and community empowerment.

While Zulkifli (2008) defines waqf as any property from which its benefits or interest may be enjoyed for any charitable purpose whether as waqf am (public waqf) or waqf khas (private 
waqf) in accordance with shariah principles. The income of waqf am goes to the baitul mal and waqf khas is applied to objects specified by the dedicator. Public waqf is statutorily defined as a dedication in perpetuity of the capital and income of property for religious or charitable purposes recognized by Islamic Law. While private waqf refers to a dedication in perpetuity of the capital of property for religious or charitable purposes recognized by Islamic Law and the property so dedicated, the income of the property being paid to persons or for purposes prescribed in the waqf.

A waqf is under the context of charity "sadaqah". It is an inalienable religious endowment in Islamic law, typically donating a building or plot of land or even cash for Muslim religious or charitable purposes with no intention of reclaiming the assets. The donated assets may be held by a charitable trust. The grant is known as mushrut-ul-khidmat, while a person making such dedication is known as wakif, a donor (Ariff, 1991). In Ottoman Turkish law the waqf was defined as usufruct state land (or property) of which the state revenues are assured to pious foundations (Wikipedia, 2016). Usufruct means the right to enjoy the use and advantages of another's property short of the destruction or waste of the substance.

The governance of waqf properties in Malaysia is under the supervision of each state's jurisdiction, that is the State Islamic religious Council (SIRC). According to Zulkifli (2008), it is estimated that there are 35,727 hectares of waqf land in existence in Malaysia, out of which $20,735.61$ acres are registered. However, as at 2009, there are 9,937 hectares of waqf land, worth RM 1.9 billion has yet to be developed (Isa, Ali \& Harun, 2011).

Zulkifli (2008) stated that most of waqf properties are mosques, religious places, Islamic schools and cemeteries, and very few of waqf lands generate income to the Islamic Religious Councils. Example is the income derived from monthly rental of waqf properties managed by the SIRC of Federal Territory only contributed a sum of RM 15,745. According to JAWHAR, there is more than RM $1.9 \mathrm{~b}$ worth of waqf land in Malaysia as at year 2009. However, according to Zulkifli (2008), there are a lot of undeveloped waqf lands throughout Malaysia. He quoted an example of Johor with 926.6 acres or 71 percent of the total waqf land is reserved for cemetery, 216.8 acres or 19 percent for mosques, 90 acres or 6.9 percent for suraus and one acre for other purposes. In Perak, there are 1,233 lots of waqf land which is equivalent to 5,122 acres with only 56 units of shop-houses and residential units being built on them, and the rest have been left undeveloped.

Theoretically if waqf assets are managed effectively and optimally, it will certainly provide a healthy return to the economy. However, literatures indicate improper management, legal obstacles and incomplete database as possible determinants of poor governance of waqf. Previous studies highlighted that there is lack of management of waqf in most of Muslim countries. It seems that there is no transparency and lack of accountability in managing waqf assets. Consequently, waqf institutions failed to function in ensuring social sustainability.

The aim of this study is to shed light on a better understanding of the problems related to waqf governance. Consequently, it is hoped that the role of good waqf governance, especially among Muslim societies, could be enlightened. 


\subsection{Literature Review}

Waqf institutions could enhance socio-economic contributions of Muslims in many ways. The models of Islamic banking and finance have been linked with the institutional and welfarist concept of sustainability that aims at the well being of society (Aliyu et al., 2016, in Research Workshop on "Revival of Waqf for Socio Economic Development" 2017). It seems that Islamic social finance such as waqf and zakat are functional as the instruments for socio-economic development of the masses.

Sultan Nazrin Shah (2018) thought that the waqf institution needs to develop its own formal governance framework in order to strengthen governance within waqf infrastructure and develop a broader strategy to revive the use of waqf as a platform for Islamic social finance. In his speech at a forum in Kuala Lumpur, he reiterated that the framework might include clear specification of the roles and responsibilities of the waqf trustee and authority, as well as a code of conduct outlining the need for the trustees to act in good faith in the best interest of the donors and beneficiaries. According to His Highness the Sultan, the biggest impediment to the development of the waqf system was the perceived poor management of waqf institution, as a result of limited regulation and supervision mechanism. In order to establish effective governance, all waqf governing bodies must have the experience and expertise required in the asset-management role and this includes ensuring that waqf authorities possess the necessary understanding of the Islamic principles and laws which govern waqf (Sultan Nazrin Shah, 2018)

Historically, wagf institutions have played an important role in the socio-economic development of Muslim ummah. Good management of charity foundations in Islam, specifically waqf, plays a crucial role in the development of the ummah, by narrowing the social distance and reducing the income disparity in the economy (Nor Aishah et al.,2014). In the same period of time, Farhana Mohamad Suhaimi et al (2014) found that share waqf plays an important role in the economic development. In a more recent research, Azniza Hartini Azrai et al (2018) suggested that return from cash waqf investment in unit trust can be used to finance items from federal government expenditures.

Salman, Abdul Ghafar and Muhammad Hakimi (2017) suggested that waqf institution could harness the potential of selfless charitable giving in an effective way for better economic impact in the targeted social segments of a society. An efficient waqf governance should help to preserve valuables either in the form of cash or non-cash fixed asset earned from voluntary but permanent distribution of wealth in an Islamic society.

Islam demands its followers to practice altruaism in the name of justice and brotherhood. One way of implementing this is through waqf practice among Muslims (Nor Aishah et.al., 2014). Altruism is the willingness to do things that bring advantages to others. It is the practice of disinterest and selfless concern for the well-being of others. In a research done by Noor Suzilawati et al. (2014), in Iskandar Malaysia, in the southern part of Peninsular Malaysia, found that more cooperation and attention from the local authorities, stakeholders and public are needed to ensure sustainable development of socio-economic which will result in increasing the quality of life of the people.

Looking back into history and strengthened by several hadiths, it seems that the specific full-fledged Islamic legal form of endowment called waqf dates from the ninth century. Most 
literatures presented elements similar to practices from pre-Islamic cultures, The word waqf originated from the Arabic Language which is "waqafa-yaqifu-waqfan" which is derived from the verb (وقف ( وقن ) . Literally it means "detention', "to prevent", "to restrain". According to alHaddad, waqf originated from Arabic word "qaf" which means stop and to prevent, which actually means to restrain the rights of the donor or the waqif to the property whether in continous ownership or in consumption. It is to be given as charity in the way of the Almighty Allah. In other words, waqf property is being transferred in terms of ownership from the donor to Allah swt and to be given in the way of Allah as in charity. It is a very important instrument in the economy of the Muslims since it is promised to be given the consent from Allah swt (al Haddad, 2008).

Iman Abu Hanifa said that the legal meaning of waqf is the detention of a specific thing in the ownership of waqf and the devoting of its profit or products "in charity of poors or other good objects". While Iman Abu Yusuf says that waqf signifies the extinction of the waqif's ownership in the thing dedicated and detention of all the things in the implied ownership of God, in such a manner that its profits may revert to or be applied for the benefit of mankind. The above elaboration is reflected in the sayings of Allah saw which is mentioned in Surah al-Imran verse 92:

Never will you attain the good [reward] until you spend [in the way of Allah ] from that which you love. And whatever you spend - indeed, Allah is knowing of it.

(in Quran 3:92)

Nor Aishah et. al. (2014) highlighted that the main problems related to waqf administration in Malaysia are the inefficient management of waqf assets and the unsystematic waqf management systems within the states in Malaysia. They further elaborated on the growing concern of mismanagement in these institutions, such as frauds and inefficiency, which may discourage the potential waqf donors to support such practice.

Isa, Ali \& Harun (2011), pointed out that in Malaysia, the management of waqf assets which is vested under the SIRC, is reported to be incapable of managing the assets effectively. The reasons are due to ineffective management of the organization, lack of expertise and financial support and also incomprehensive law and enactment. Whilst,Shatzmiller (2008), found that waqf management problems could be expressed in two ways: in the procedure, which is the daily operations of waqf management and in the lack of economic growth. It pointed out to institutional misconduct causing in loss of revenue, disruption of work, misperception, augmented costs, waning revenue or no income at all. The yields for both the institution and society were insufficient and in several cases completely lacking.

Another issue in the governance of waqf is the loopholes in the legal framework. Waqf administration is regulated through various state laws or enactments. There is no specific statue on management and administration of waqf except the Enactment of Wakaf (State of Selangor) 1999 and the Enactment of Wakaf (state of Malacca) 2005. Therefore, there are a lot of administrative problems raised by the existing procedures such as improper forms and others (Zulkifli, 2008).

Generally, Muslims do not have a clear picture of the immovable concept of waqf (Haslindar et al., 2013). They think that waqf only permits immovable property to be donated. 
It seems that not only individuals but governments in general have not utilized the benefits of the waqf concepts. Mohamad et al.(2005) in Haslindar et al., (2013) stated that the lack of effort of Muslim scholars and jurists during the last two centuries has caused the impediment of waqf properties. Otherwise, successful waqf governance will generate wealth to Muslim countries, which will indirectly contribute towards the economic growth and sustainability.

In this study, it is proposed that good waqf governance could act as a catalyst in achieving sustainable development, especially in Muslim-majority countries. The idea for the current research is based on previous literatures from different continents of the world as has been discussed above.

\subsection{Methodology}

To achieve the aim of this study, which is to shed light for a better understanding of the problems related to the role of waqf governance in achieving sustainable development, a qualitative research design is adopted. This is a non-conclusive study and exploratory in nature. Initially, a literature study was done to determine the possible reasons of existing problems pertaining to waqf governance. Then, in order to obtain a clearer picture of the problem at hand, a qualitative primary data is collected by using depth interview as the tool and was executed during a case study on Kelantan State Religion Board (MAIK). The MAIK's waqf offocer was interviewed to obtain more detailed explanation.

Depth interview is a qualitative research technique that involves conducting intensive individual interviews to explore the respondents' perspectives on a particular idea or situation. It is a loosely structured interview. It allows freedom for both the interviewer and the interviewee to explore additional points and change direction, if necessary. A depth interview is preferred in this study since we are aiming for detailed information. Furthermore, this technique offers opportunity to capture rich, descriptive data. And it can be used as a standalone research method or as part of a multi method design. Nevertheless in this research it is used as part of the methods, to complement the initial literature study done.

MAIK, the authority which is responsible for the implementation of waqf in Kelantan, a state in the Peninsular of Malaysia is the institution under study here. In an effort to explore the chosen issue, on 20 th March 2017, the researchers interviewed MAIK's Waqf officer who represented the Waqf and Baitulmal Unit. In the organizational structure of MAIK, there are three main divisions, which are the Managerial Service Division, Development Division and Religious Affairs/Mosque Division. Each division consists of several smaller units. Waqf Unit is under the Development Division, together with Zakat Collection Unit, Baitulm Unit and Waqf al Unit and Ehsan Fund Management Unit. Before 2013, Baitulmal Unit and Waqf Unit are placed under the same division, however these two units are segregated now since the managerial works has become bigger and contributions come from different sources. Baitulmal Unit manages inheritance, non-sharia compliance money, luqatah and etc. The Waqf Unit is the department which is responsible for waqf governance in the state of Kelantan.

Open-ended questions were constructed and were posed to the Waqf officer of MAIK. Examples of the questions are "What are the main challenges faced by MAIK pertaining to 
the governance of waqf contributions in Kelantan?" "Is there any part of the legislation system that could undermine the governance of waqf institution in Kelantan?"......... The answers to the questions are recorded, transcribed, analyzed and discussed.

However, the limitation of this research technique is that depth interview could be prone to bias. Additionally, since this is a qualitative non-conclusive research, generalization of the result is not able to be made. The findings from depth interview in this study, is not generalizable to other state religious boards.

\subsection{Results and Discussion}

In Malaysia, waqf properties are under the governance of each state's jurisdictions, that is the State Islamic Religious Council (SIRC). Waqf affairs in Malaysia are the responsibility of the SIRC of each state. The courts recognize shariah as the governing law of the property for Muslims including waqf. Section 25 of the Civil Law Act 1956 stated that the administration of Muslim's property shall be in accordance with the Islamic Law.

There are 14 State Islamic Religious Councils in Malaysia, one for each of the 13 states in Malaysia and one for the Federal Territory. The government of Malaysia has formed the Department for Zakat, Waqf and Hajj (JAWHAR) on the $27^{\text {th }}$ March 2004, with the aim of making the administration of zakat, waqf and hajj systematic and effective. This department however does not have the authority to administer and manage waqf properties, but rather plays as a planning coordinator and observes the waqf matters (Zulkifli, 2008). He further added that JAWHAR has formed Yayasan Wagf Malaysia (Malaysian Waqf Foundation) for the sole purpose of identifying the underutilized assets of awaqf and planning for their development in coordination with the SIRC of each state. In actual fact, this is a good move by JAWHAR. Zulkifli (2008) also said that the investment of waqf land could be supported by the federal or state government or statutory bodies or financial institutions. Of utmost importance is the ability of the waqf institution to choose the most supporting and suitable methods of financial schemes for any of its investment project.

In Kelantan, MAIK started to govern waqf institution since 26 December 1899, which falls on 22 Syaaban 1317 Hijiah. At that instance, the institution was directly supervised by His Highness the Sultan of Kelantan. Among the first waqf contributions managed by MAIK was waqf asset contributed by Tengku Kaya Pahlawan Kelantan (a state dignitary). On the other hand, cash waqf was recently launched in 2015 and is quite well received by the people. The total for cash waqf under MAIK's supervision is amounting to one million ringgit Malaysia, as at March 2017. This cash waqf is allocated for general waqf and educational waqf, such as the construction of the hostel building for one religious school in Kelantan. MAIK also received buildings and land as contribution for waqf.

Revenues or benefits from waqf assets are being used to pay for the maintenance of those waqf assets which are not generating any revenue, such as mosques. MAIK also need to pay for the quit rent or the assessment rate of waqf land. Graveyards on waqf land also need to be maintained.

Waqf land management is very legal binding. If there is a legal instrument for the waqf property, then MAIK will have to follow strictly what are stated in the document. For instance, 
if the contributor's intention is stated in the document for the given land to be used as a graveyard, then it is compulsory for MAIK to comply with the stated intent of the contributor. It should be highlighted that sometimes a piece of waqf donated land is intended to be used as a premise for a mosque (as stated in the legal instrument) but the fund for the construction of the mosque itself is not contributed together with the land by the donor. Without the fund, the intention of building a mosque could not be easily tranformed into action. MAlK would have to look for the funding elsewhere - which is clearly not easily done. Furthermore, in many cases, thre are mosques which are already built in the same neighbourhood .This entails in redundancy if another mosque is to be built in that area. These are some of the reasons why there are several waqf lands lying dormant, without being developed and the solutions for these problems are yet to be found.

There are a lot of challenges faced by MAIK in managing waqf assets and properties in Kelantan. These challenges could be in the form of minimal revenues generated from waqf properties and limitations in the usage of waqf assets due to the binding legal framework. Apart from the tying of waqf assets to legal instruments, waqf am or general waqf are said to be non-revenue generating assets. At the same time, fund is needed to maintain and to manage these assets. Clearly, these practices will end up in additrional expenses to be borned by MAIK.

Next issue is the undersized human resource in the management team in MAIK. An employee in the Waqf and Baitulmal Unit in MAIK needs to be multi-tasking. One worker would have to perform several tasks. As a result, many tasks could be delayed due to the shortages in man power. This problem is very much related to the polices of Kelantan state government

Another significant factor is weak data base management. Information technology expert is non-available in MAIK, which entails in many data base related issues. Records of waqf lands are still done manually. Retrieval of data could be very tiresome and time consuming. The present data of the total acreage of waqf land is compiled manually and are stored in hard copy files. This could lead to difficulties in data accessibility and the updating process of the data.

In furtherance to the above issues, the contributors of waqf assets or the donors themselves are lacking in the understanding of the procedures concerning waqf. Some of the donors are having the notions that they are donating their lands (assets) to MAIK only and not to Allah swt. It has to be clearly understood that once the land is donated as waqf land, it is irrevocable. The agreement or the contract cannot be undone. MAIK is trying its best to create awareness among the public, though the efforts are still far from being adequate.

When Waqf Unit in MAIK is understaffed, rental collection problems arise. There are more than 500 premises being rented and managed by the Waqf Unit of MAIK. Therefore, the task of rental payment collection could be very challenging when the unit itself is somewhat understaffed. It should be noted that not having an efficient data base management enlarges this problem.

Fairly said, some of the data and information concerning MAIK that has been released by JAWHAR and Malaysian Waqf Board may have some inaccuracies. According to JAWHAR, waqf lands that are used as graveyards and for mosques constructions are 
considered as 'undeveloped waqf land'. No detailed and thorough studies have been carried out on waqf governance in Kelantan and in the past MAIK might have been misrepresented to the public. MAIK has to face many incidences of 'finger pointing' and has to bear a bad image. Thus, a redefinition of 'undeveloped waqf land' is needed, to say the least.

In terms of procedures, the Waqf Unit of MAIK has to comply with the Kelantan Land Office. Not many issues arise but the regulations change at times. Every procedure has to be followed to ensure smooth transfers of land ownerships from the donors to MAIK. Waqf governance matters have to be referred to the Mufti, the state religious advisor. If and when needed, cases have to be brought to state religious board meetings and be posited for the Sultan's approvals. The pending periods are undetermined. This worsen the problems related to waqf governance and hinders sustainable development.

\subsection{Conclusion}

Conclusively, it can be said that legislations and inefficient management are among the main possible impeding factors for good governance of waqf which could then imflict upon the effort of achieving sustainable development, especially in countries with muslim majority population. The issues in legislation pertaining to waqf land are not easily resolved. A concerted effort from many parties are needed to reach a solution. The same goes for turning over into an efficient organization. A lot of improvement are called for that long road towards sustainable development.

Waqf brings together both the spiritual and material elements. Based on its nature, waqf should be able to act as the catalyst for economic growth as well as the human development, if the institution is systematically and optimally governed. However, despite possessing the potential of improving the society, a substantial proportion of total waqf is still lying dormant across the world. New frameworks and models for waqf governance have been proposed by several scholars but as yet to be tested. Socially, waqf enables the birth of responsible and accountable citizens which will eventually promote the quality of life. A society that possesses the quality of life will help to promote sustainable development.

The waqf authority may consider various financial schemes and instruments appropriate to waqf real estate development. The SIRC is proposed to set up its waqf corporate entity in the form of waqf holding or a waqf development corporation. It is believed that the establishment of the waqf development corporation would enable the SIRC to arrange various finance schemes for the investment of waqf land. Then the councils will not be exposed to liabilities arising from a particular development. The hope is for the indoctorinism of professionism and to ensure effective management of waqf land.

It is thought that the waqf institution needs to develop its own formal governance framework in order to strengthen governance within waqf infrastructure and develop a broader strategy to revive the use of waqf as a platform for Islamic social finance. To be considered also is the revival of idle, immovable waqf assets through the adoption of new innovative contracts of Islamic finance, such as Musharakah Mutanaqisah (Diminishing Partnership) and Build-Lease-Transfer arrangements. The movable waqf assets may be in the form of cash waqf models such as waqf shares, mobile waqf and corporate waqf. The 
hope is that eventually the practice would trigger the achievement of sustainable development.

In furtherance, there are four main ideas which can be applied for the improvement of waqf institutions, namely internal financial control, transparency and reporting, management of funds and code of Good Governance. Besides, there is a need concerning legal reformation of waqf, whereby the government of Muslim countries should consider to re-evaluate waqf acts. Furthermore, educational institutions have a role pertaining to educate people to be aware of creating better people with better quality of life. Then the attention to waqf institutions can be improved gradually.. Hopefully, the findings of this research could help in improving the performance of waqf institutions in the future and they will be able to promote sustainable development especially among the Muslim communities.With the present revival in waqf practices throughout the world, good governance and best practices of waqf institutions are very much called for.

\section{Acknowledgement}

The authors' heartiest appreciations are due to Madam Shakirah Mohamad, the Waqf Officer of the Waqf and Baitulmal Unit, Kelantan State Religious Council (MAIK), for the invaluable information given during the personal interview on the $20^{\text {th }}$ of March 2017.

\section{References}

al-Haddaad, Ahmad Abdul Aziz (2008). Min Figh al-Waqf (From the jurisprudence of the waqf). Islamic Affairs \& Charitable Activities Department.

Anand, S. \& Sen, A.K. (1996). Sustainable human development: concepts and priorities: Office of Development Studies Discussion Paper, No. 1, UNDP, New York

Ariff, M (1991). The Islamic voluntary setor in Southeast Asia, Institute of Southeast Asia Studies, pp 42J.KAU: Islamic Econ., Vol. 8,http://waqfacademy.org/wp-content

Azniza Hartini Azrai, Azaimi Ambrose, Mohamed Aslam Gulam Hassan \& Hanira Hanafi (2018). "A proposed model for waqf financing public goods and mixed public goods in Malaysia", International Journal of Islamic and Middle eastern Finance and Management, Vol. 11 Issue: 3, pp. 395 - 415, https://doi.org?10.1108/IMEFM -01-2017-0001

Farhana Mohamad Suhaimi, Asmak Ab Rahman \& Sabitha Marican (2014). "The role of waqf share in the socioeconomic development of the Muslim community: The Malaysian experience", Humanomics, Vol. 30, Issue:3, pp 227-254, https://doi.org/10.1108/H-12-2012-0025

Haslindar, I., Afizar, A. \& Tajul Ariffin, M. (2013). Cash waqf: An economic instrument for economic development. International Review of Social Sciences and Humanities,Vol 6, No. 1, pp 1 - 7

International Islamic University Malaysia. Retrieved on 2017, http://www.llum.edu.my

Isa, Z.M., Ali, N. \& Harun, R. (2011). A comparative study of waqf management in Malaysia. In 2011 International Conference on Sociality and economics development (Vol. 10, pp. 561 - 565) 
Islamic Development Bank (2014). Waqf \& Zakat: Solidarity-baed financing for sustainable development, https://sustainabledevelopment.un.org/content/....

Department for Zakat, Waqf and Hajj (JAWHAR), 2009

Monzer, K. (2011), Financing The Development of Waqf Property", dalam Essential Reading in Contemporary Waqf Issues, ed. Monzer Kahf and Siti Mashitooh Mahamood (Kuala Lumpur: CERT).

Noor Suzilawati, R., Mariana, M. O. \& Shahirah, B. (2014). Economics of local people: Iskandar, Malaysia. ProcediaSocial and Behavioural Sciences (53) (2014) pp. $463-478$

Nor Aishah, M.A., Abd Halim, M.N., Aryani, A. \& Henny Hazliza, M.T. (2014). The waqf governance framework in Malaysia, Conference Paper at International Conference on development of Social Enterprise and Social Business for Eradication of Extreme Poverty and Street Beggin. At University of Chittagong

Patmawati, I., Siti Arni, B. \& Asmak, A. R. (2011). Sustainable economic development: Concept, principles and management from Islamic perspective. European Journal of Social sciences, Volume 24. Number 3, pp 330 - 338. Research Workshop on "Revival of Waqf for Socio Economic Development", 2017 organised by IRTI, IBBL and CZM Dhaka, Bangladesh.

Salman, A.S., Abdul ghafar, I. \& Muhammad Hakimi, M. S. (2017). Application of Waqf for Social and Development Finance, ISRA International Journal of Islamic Finance, Vol. 9 Issue 1, pp 5 - 14 (https://doi.org/10.1108/JIF-072017-002)

Shatzmiller, M. (2008). Islamic institutions and property rights: The case of the 'Public Good' waqf. Journal of the Economic and Social History of the Orient, 44(1), 44 - 74

Sultan Nazrin Shah (2018). Waqf: Gaining the trust for social economic sustainability. Higher Education Forum 2018: Waqf Revival. Kuala Lumpur

United Nations (2014). Prototype Global Sustainable Development Report (http://sustainabledevelopment.un.org/globalsdreport/) (Online unedited ed.). New York: United Nations Department of Economic and Social Affairs, Division for Sustainable Development.

Zakaria, A.A.M., Abd Samad, R.R. \& Shafii, Z. (2012). Venture philanthrophy - Waqf practices and its implementation scenario in Malaysia. International Journal of Business, Economics and Law, 1, 108 - 115.

Zulkifli, H. (2008). Islamic law of property, https://zulkiflihasan.files.wordpress.com/2008/..../administration-of-waqfin-malaysia....

http://www.social-life.co/publication/Social-Sustainability/

https://quran.com/3/92

https://en.wikipedia retrieved on 20 December 2016 